\title{
Contextuality and the Septuagint
}

Author:
Johann Cook ${ }^{1}$
Affiliation:
'Department of Ancient
Studies, Stellenbosch
University, Stellenbosch,
South Africa
Corresponding author:
Johann Cook,
cook@sun.ac.za
Dates:
Received: 12 Apr. 2018
Accepted: 16 Sept. 2018
Published: 04 Apr. 2019
code with your
How to cite this article:
Cook, J., 2019, 'Contextuality
and the Septuagint',
mTS Teologiese Studies/
to read online
Theological Studies 75(3),
a5029. https://doi.org/
10.4102/hts.v75i3.5029
Copyright:
C) 2019. The Authors.
Licensee: AOSIS. This work
is licensed under the
Creative Commons
Attribution License.

This article will emphasise that the time has arrived for another phase in LXX research that goes beyond text-critical studies. Studying the Septuagint entails dealing with translated literature, which requires an appropriate methodology. The truth of the matter is that the Septuagint (the Old Greek) is a translation of a translation. Therefore, translation studies (TS) come into play. It is, moreover, important to determine the translation technique followed by a translator, which should be done in conjunction with TS. Finally, in order to understand the Septuagint (the exegesis of the LXX), addressing issues of contextuality is a sine qua non. The Septuagint version of Proverbs is used as a case study. This article will argue that the context in which this translated unit came into being was an apocalyptic one, inter alia, because of the devastating reforms of Antiochus Epiphanes.

Keywords: Septuagint; Textual criticism; Hermeneutics; Theology; Translation technique; Paradigm; interlinear; Antiochus Epiphanes.

\section{Methodological considerations}

It is a pleasure to contribute to the Festschrift in honour of Prof. Eben Scheffler. He is one of the members of the scholarly associations of Old Testament Society of South Africa and New Testament Society of Southern Africa who takes the Septuagint seriously in his research. Moreover, he always encourages me in my own research.

This author recently published a reminder that the time and opportunity have arrived for hermeneutical studies of the Septuagint (Cook 2017:1-22). The focus should be on understanding the Septuagint, not exclusively on establishing the Septuagint. ${ }^{1}$ Various issues are of critical importance when one attempts an interpretation of the Septuagint. These issues include establishing an acceptable base text - in the case of the LXX a source text, or rather two source texts (a Hebrew text and a Greek text) and two target texts (Cook 2006). The translation of the Septuagint is after all a translation of a translation. It is important to acknowledge that the Old Greek (OG) texts are translated literature, because the same methodology cannot be applied as to compositional literature. Without an appropriate methodology - in the sense of a suitable theoretical paradigm for textual studies (Septuagint Studies) - we will not make much progress (Naude 2009:262f.).

\section{According to Bassnett and Trevedi (1999):}

Translation does not happen in a vacuum, but in a continuum; it is not an isolated act, it is part of an ongoing process of intercultural transfer. Moreover, translation is a highly manipulative activity that involves all kinds of stages in the process of transfer across linguistic and cultural boundaries. Translation is not an innocent, transparent activity but is highly charged with significance at every stage; it rarely, if ever, involves a relationship of equality between texts, authors or systems. (p. 2)

\section{A paradigm for Septuagint studies}

There are three prominent translational projects ${ }^{2}$ of the Septuagint on the research market: the interlinear model of the Canadian school (Albert Pietersma and Benjamin Wright III), the freestanding replacement translation of the French La Bible d'Alexandrie (Madame Harl) and the reception-oriented approach of LXXDeutsch (Wolfgang Kraus et al.) (Cook 2017:7f). Each one has strong and weak points (Naude 2009:269f). For example, NETS focuses exclusively on the OG, whereas the French model includes the reception of the Septuagint, especially among the church fathers. The doctoral dissertation by Boyd-Taylor (2005:ii), entitled 'Reading between 1.Prof. Frank Charles Fensham insisted that text-critical issues should not be the ultimate focus of scholars. See also Boyd-Taylor (2005:9). 2.There are, of course, more projects. See the IOSCS website.

Note: The collection entitled 'Eben Scheffler Festschrift', sub-edited by Jurie H. le Roux (University of Pretoria) and Christo Lombaard (University of South Africa). 
the Lines - Towards an Assessment of the Interlinear Paradigm for Septuagint Studies', provides a conceptual and methodological groundwork for a principled assessment of the interlinear paradigm for Septuagint studies and is useful. The paradigm is an informal theory purporting to describe the model of translation underlying much of the Septuagint corpus (Boyd-Taylor 2005:8).

A fundamental aspect of an appropriate paradigm should be the realisation that the Septuagint OG is a corpus of translational literature (Boyd-Taylor 2005:8), even though de novo Greek compositions make up a substantial part of the Septuagintal corpus and should be treated differently. This type of literature is different from compositional literature. According to Boyd-Taylor (2005:8), the fundamental task of scholarship is to account for these various translations as facts of the cultures that produced them (Toury 1995).

Here, the field of translation studies (TS) comes into play and the impact of Toury's work (1995) is significant. According to Boyd-Taylor (2005:8), 'Descriptive Translation Studies [DTS] provide a clearly defined analytical framework within which translational texts can be characterized and typologically differentiated qua translations'. He also argues that the notion of acceptability, which may be defined as a translation's relative conformity to the linguistic, textual linguistic and cultural conventions underlying textual production in the target language, is fundamental to DTS (Boyd-Taylor 2005:8). In the light of this view, it is not difficult to see why the interlinear model is deemed the best suited for Septuagint Studies by some scholars. However, not everybody agrees (see Naude 2009:269). In the final analysis, the interlinear paradigm is meant to indicate a linguistic relationship between two texts, one in Hebrew (Aramaic) and the other in Greek, and the term 'interlinear' indicates a relationship of subservience and dependence of the Greek translation vis-àvis the Hebrew (Aramaic) parent text (Pietersma 2002:346)

It is imperative to distinguish between the production and reception of texts. Septuagintal scholarship is characterised by the production of translational literature. As said before, studying this literature requires an appropriate methodology that is different from the methods construed for compositional literature. It is, moreover, the task of Septuagint Studies to account for the translations as facts of the cultures that produce them. This dimension of a translation is referred to as its constitutive character (Boyd-Taylor 2005:8).

\section{Towards a theory of translation}

A fundamental concept in the formulation of a suitable theory of translation is the constitutive character of a text. When a translated text is considered with respect to the historical enterprise which gave rise to it, namely its originating Sitz im Leben, it becomes readily apparent that the verbal character of the document will to some extent reflect the socio-linguistic practices proper to the larger cultural undertaking of which it was a part. According to Boyd-Taylor (2005:32), this aspect of the text might be called its constitutive character.
Another truism for the Septuagint scholar is that the task of interpretation is related to questions of a historical nature. Toury's threefold schema of function, process and product acts as an appropriate analytical frame of reference within which the constitutive character of the texts can be conceptualised (Boyd-Taylor 2005:52). In this regard, the translator is seen as an indispensable cultural mediator.

\section{Translation technique}

Determining the way a translator rendered his parent text assists the researcher to ascertain the way that this translator approached this Semitic parent text. Descriptions such as 'literal' and 'free' have been employed, with limited success (Tov \& Wright 1985). Hence, novel methods have been developed to address this problem.

There has been much progress as far as the study of translation technique in the Septuagint is concerned. Michael Fox (2015) prefers to speak about 'mimetic' translation instead of 'literal'. A mimetic translation:

attempts to map the maximal number of linguistic features of the source onto the receptor text and aims at consistency in correspondences between the vocabulary of the source and the target. (p. 4)

He goes on to describe the translator of LXX Proverbs as 'flexible' rather than 'free' (Fox 2015:5). He then rightly maintains that one must proceed verse by verse to note how closely or broadly the translator maps the source text onto the target text (Fox 2015:6).

Hans Ausloos and Bénédicte Lemmelijn have also ventured new ways to address this issue by developing content- and context-related criteria in order to refine the process (Ausloos \& Lemmelijn 2010:356-376; Ausloos, Lemmelijn \& Kabergs 2012:273-294). In addition, a relatively recent development, poly-system studies, has been utilised in order to research ancient texts (Evan-Zohar 1990:9-26). In the final analysis, there is a consensus that the persons responsible for LXX Proverbs had a free hand in introducing new interpretations of the OG in the translation.

Be that as it may, the translator(s) of LXX Proverbs had a unique approach towards the parent text. This is observed on a micro level and also on a macro level. As far as the first goes, some individual lexical items are rendered consistently, but many are varied. This translation technical approach can be described as one of diversity and unity (Cook 2001:208). This approach, however, does not prevent the translator from interpreting in individual instances, even where a generally consistent way of translation is followed in respect of a specific Hebrew word. This translation unit also exhibits unique features on the macro level. The order of some chapters towards the end of the book that differ from, inter alia, the MT should be ascribed to its translator(s), which is borne out by the removal of the names of Agur and Lemuel, who are mentioned as authors of some Proverbs in the Hebrew. This removal has to do with the fact that Solomon is deemed, 
as stated in 1:1, the sole author of the Proverbs. It is clear that Solomon is assigned a special position in the Greek version. The author ascribed this interpretative approach to the translator's ideology (Cook \& Van der Kooij 2012:132), which is characterised by a conservative Jewish religious attitude. This inference is based on, inter alia, the prominent role of the Law of Moses in LXX Proverbs. Because of the influence of Hellenism in the Jewish society, it became necessary to enhance the role of the torat Moshe.

\section{Historical exegesis and translational literature}

According to Boyd-Taylor (2005:426), the passage from philology into exegesis is fraught with danger. It is important to determine what should be understood under the rubric 'exegesis'. Various scholars have suggested possible interpretations (Cook 2017:14). What is clear to me is that the 'theology/exegesis' is to be located in the way any given translator, in fact, renders his parent text. It is in the differences between the source text and the target text that interpretation becomes evident. This interpretation could be understood as exegesis or theology (Cook 2017:13).

A number of issues are pertinent in this regard. Firstly, scholars tend to read certain aspects of NT exegesis back onto the Septuagint text itself (Boyd-Taylor 2005:22). Naturally, this should be avoided. Secondly, Pietersma distinguishes between a maximalist and minimalist interpretation of the Septuagint. As far as the first is concerned, he refers to scholars who think 'the Greek translator is effectively elevated to the status of an author' (Boyd-Taylor 2005:24). ${ }^{3}$ Finally, according to Boyd-Taylor (2005:429), historical exegesis must rest squarely on the character of the translation as a literary product. And again, DTS come into play. As to the framework for Septuagint Studies, as proposed by Toury, it is one of function, product and process. An important fact is that insights come from the larger context (Boyd-Taylor 2005:83).

\section{Contextuality}

It is a common fact that each (OG) TEXT came to be in a given CONTEXT. There is no consensus on the provenance of the Septuagint of Proverbs. Some scholars take the Aristeas book literally ${ }^{4}$ and think that all of the LXX actually was translated or construed in Alexandria. This surely applies to the Pentateuch. Others leave scope for other contexts, such as Palestine. In an article entitled 'Reflections on the Septuagint with special Attention paid to the Post-Pentateuchal Translations', Emanuel Tov (2010:4) addresses six questions relating to the post-Pentateuchal versions:

3.This would certainly apply to freely rendered units. See Rösel (2008:83-102) who argues that LXX translators could be deemed authors, translators and theologians. According to him:, ist es deutlich, dass die Arbeit der übersetzers der theologians. According to him:, ist es deutlich, dass die Arbeit der Ubersetzers der Septuaginta nicht nur eine bedeutende sprachliche, sondern auch eine eminen wichtige theologische Leistung ist, durch diese Version der Bibel zur vp $\alpha \varphi$ i und Grundlage des Christentums geworden ist' (Rösel 2008:102). See also Cook
(1995:12).

4.John Wevers (1985:17) again thought that the book of Aristeas had no historical value at all.
1. Are the post-Penteuchal versions Jewish? The following evidence is offered by Tov: a. Reliance on the Greek Torah by the late translators; $b$. Midrashic tendencies; c. Jewish background of LXXIsaiah; and d. Jewish exegesis in LXX Proverbs.

2. Place of origin. The Alexandrian background of these books is unjustifiably assumed. There is no real hard evidence. Tov (2010:9) quotes evidence of possible Palestinian origin: (i) The colophon of the Greek Esther; (ii) Ecclesiastes translated in Palestine by Aquila or kaigeTh.; (iii) Sections of Samuel-Kings; (iv) Canticles; (v) Lamentations; (vi) Ruth; (vii) Psalter; (viii) 1 Esdras and Daniel; (ix) 1 Maccabees; (x) Judith and Tobit.

3. The nature of the translation enterprise. Tov (2010:16) rejects the idea that the books were translated as official projects. He prefers to think of individual units.

4. Heterogeneity of Greek scripture. He finds the heterogeneous character of the Greek Scripture striking (Tov 2010:17); from a textual point of view, the choice of texts is coincidental.

5. The gradual development of the collection of translations. Tov asks whether there was indeed an organisational force behind the collection of texts.

6. The Hebrew text underlying the LXX. Some/many of the texts that were translated came from Palestine. There are no Egyptian features in the Hebrew Vorlagen (Tov 2010:22).

In the following, the author briefly argues that the Septuagint of Proverbs came to be in Palestine. In order to determine the context, specific criteria need to be applied. There are basically three sets of criteria: firstly, linguistic ones and more specifically lexically based criteria; secondly, arguments from content analysis that provide insight into the context in which any given unit came to be written; thirdly, one can also compare external data in order to determine the provenance of a specific book (Cook \& Van der Kooij 2012:89).

Regarding the first set of criteria, the author undertook numerous linguistic analyses (Cook 1997; Cook \& Van der Kooi 2012:94f). There is consensus that this unit exhibits a rather free translation technique (Tov \& Wright 1985:186), but this term, like 'literal', ${ }^{5}$ is problematic. However, the author applies them in order to define the free, less faithful and even paraphrastic way ${ }^{6}$ in which this translator rendered his parent text. The author demonstrated that the translator(s) of the Septuagint of Proverbs had a unique approach towards its parent text (Cook 1997:332). As said above, the author defined this translational approach as one of diversity and unity (Cook 2001:208). This is underscored by the rather large number of hapax legomena and neologisms that occur in LXX Proverbs (Cook 2002:2). These textual phenomena are clear signs of literary competence.

The author already dealt exhaustively with the issue of the macro-level differences between LXX and, for example,

5.Aejmeleaus (1993:122) prefers the term 'faithful' instead of 'literal'. Fox (2002:207$220)$ chose to use the term 'mimetic' in this regard. See also Van der Louw 2006.

6.See also the proposals by B. Lemmelijn (2007:1-32) regarding definitions in translation technique. See also her monograph (Lemmelijn 2009). 
MT (Cook 2003). The author is convinced that the different order of chapters compared to MT and the other major textual witnesses is the result of the translator's intervention. This is based primarily on the unique translation technique of this unit.

As far as the second issue, external data, is concerned, the author commences with the extent of the influence of Hellenism in Palestine. There is ample evidence of the impact of Hellenism in Palestine. This applies to artefacts as well as to the literature. Martin Hengel (1974:130) presents evidence that the earliest indication of the existence of a gymnasium in Jerusalem could be dated to 175 BCE. Greek names and literature, inter alia, the works of Homer, according to Hengel (1974:139), were already known in Jerusalem by the third century $\mathrm{BCE}$. The treatise by Eupolemus written by the middle of the second century BCE is a decisive piece of evidence (Wacholder 1974). It is a propagandistic history and was written in Jerusalem in Greek. ${ }^{7}$ It mentions Moses as the first wise man who handed over the letters to the Jews. From this discussion, it should be clear that Greek learning was in vogue to some extent in Palestine during the third and second centuries BCE (Hengel 1974:143).

Thirdly, some scholars connect Aristobulus, who lived and wrote in Alexandria, to the LXX. D'Hamonville (2000:134), in fact, thought that Aristobulus was responsible for LXX Proverbs. The author deems that improbable, because he had a different attitude towards Greek philosophy than the translator of the Greek Proverbs. It was Aristobulus's objective to utilise Greek philosophical insights in order to understand the Pentateuch. The author found no evidence of a positive application of such philosophical perspectives in LXX Proverbs (Cook 1997:201f.).

\section{Anti-Hellenistic tendency in LXX Proverbs}

To be sure, the author detected an anti-Hellenistic inclination in LXX Proverbs; this is important for determining the provenance of the book. LXX Proverbs came into existence in a foreign or alien, an un-Jewish and pro-Hellenistic environment in which the Law of Moses was devalued and a Greek way of life advanced. The relevant passages are, firstly, the rejection of individualisation in LXX Proverbs chapter 9 verse 12:

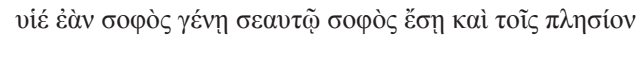

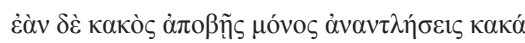

My son, if you become wise for yourself, you must be wise for your neighbours as well,

however, if you turn out evil, you will bear the evil alone.

The son is warned not to be too individualistically minded in this passage. The implication of this verse is that one has the responsibility to be wise for the sake of one's neighbours and

7.This is an important issue. According to Wacholder (1974:13): 'The Greek education of Eupolemus is of great significance, since from him we can learn what kind of training was received by the Hellenizing priests at the turn of the second century B.C' (p. 13). not for one's own sake only. Interestingly enough, there is a contrast between WISDOM and EVIL!

A second aspect is the devaluing of the torat Moshe. Proverbs 9:12-18 seems to me to be a reaction to people who are degrading the law [cf. the addition in Prov 9:10a (Chapter 13:15 too)]: 'for to know the law is the sign of a sound mind'). Because of the hostile Hellenised context, it became necessary to underscore the positive features of the torat Moshe.

A third example is the role of wisdom in LXX Proverbs. Two

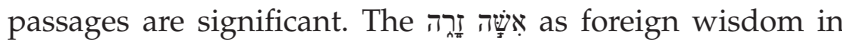
LXX Proverbs chapter 2 is the first. The chapter can be divided into two main parts: the protasis, verses $1-4$ and the rest of the chapter that makes up the apodosis. Verses 11 and 16-19 are directly relevant to the issue at stake: ${ }^{8}$

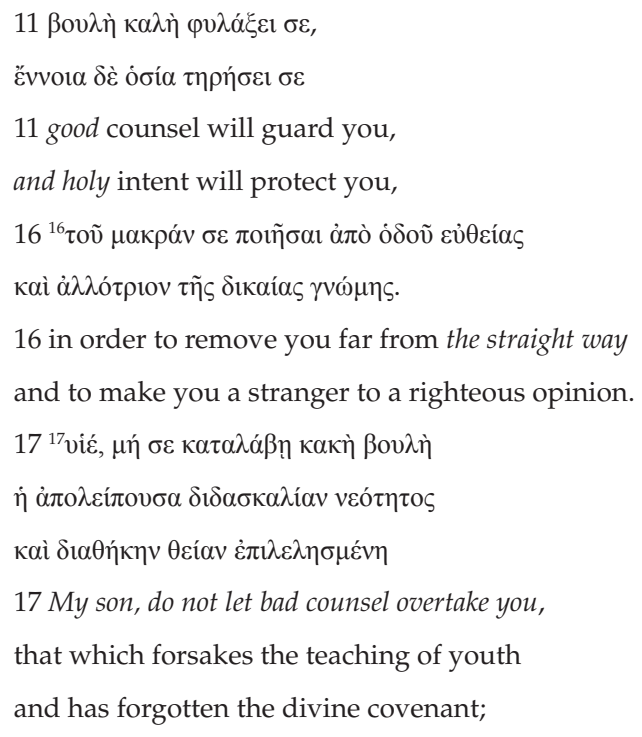

As far as contents are concerned, Chapter 2 can be divided into two parts, which at the same time is a contrast. Verses 1-12 refer to the good realm and verses 13-22 describe the bad realm. Verses 11 and 17 are significant and contain related but contrasting concepts. Verses 16 and 17 are especially crucial and contain an addition compared to MT and the other witnesses. Verse 16 in MT reads as follows:

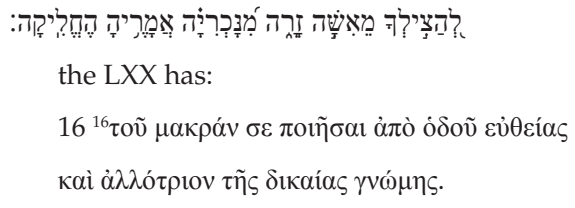

It is clear that the translator does not deliberately avoid the

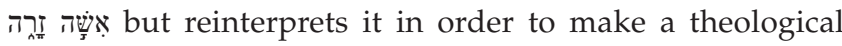
point that is expressed even more clearly by the translation of verse 17 .

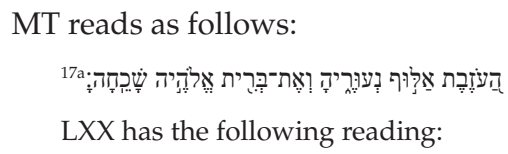




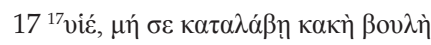

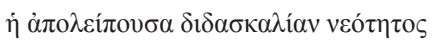

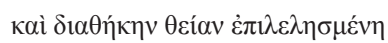

The first strophe has no equivalent in the other textual witnesses and in my view is a deliberate addition by the

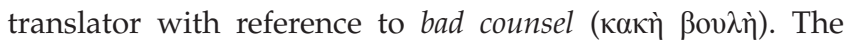

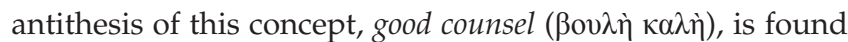
in verse 11 and is, as stated above, part of the good realm. I have indicated that these two Greek concepts are not typical Greek, but have as their cultural background the Jewish

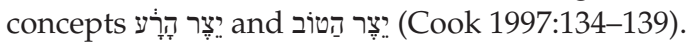

In my view, we have a conservative Jewish translator at work (Rösel 2008), who has reused typical Jewish exegetical traditions regarding the good and evil inclinations that, according to Judaism, are found in each person. It is clear that the translator did not intend to avoid the sexual issues inherent in the Hebrew - in chapter 7, a corresponding phrase is translated literally. I have taken this interpretation

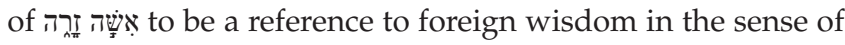
un-Jewish or non-Israelite wisdom. ${ }^{9}$

The fourth example is LXX Proverbs chapter 8, which has a different understanding of this pericope from MT. I focus on verses 30-31.

\section{VERSE 30 (see Cook 1997:33-50):}

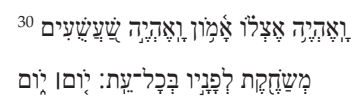

I was beside him, fitting together, it is I, who was the one in whom he took delight. And each day I was glad in his presence at every moment.

This verse is the locus classicus as far as arguments concerning the so-called Stoic colouring of the LXX. The verbal form

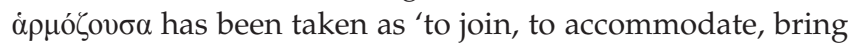
into harmony', which is then seen as an idea 'indigenous to the Stoic view of nature' (Gerleman 1950:26). The author has made a study of this passage and could find no evidence of Gerleman's interpretation (Cook 1997:246). As a matter of fact, the emphasis of the whole pericope in its Greek version is on God's activity in the creation process. Wisdom has no other role to play than that of being happy and joyful (verse 30), which also need not to be seen as an exclusive characteristic of Stoicism. Therefore, he translates $\alpha \rho \mu o ́ \zeta o v \sigma \alpha$

9.Cook, (1994), 458-476. See Seth A. Bledsoe, "Strange" Interpretations in LXX Proverbs', in XV Congress of IOSCS, 671-693, for a different view. It must be remembered that the XV Congress of IOSCS, 671-693, for a different view. It must be remembered that the
intention of these two articles is different. Bledsoe hardly deals with the Jewishness of this translated unit. His focus is on the 'strange' Interpretations. with 'fitting together', a nuance that appears in specific contexts. In his view, the translator underscores the creative role of God in the creation and underplays the independent role of Lady Wisdom.

The anti-Hellenistic inclination that the author detected in LXX Proverbs points to a context that was either already heavily Hellenised or was progressively falling under the influence of Hellenism. In general terms, both Jerusalem ${ }^{10}$ and Alexandria fit this description. The problem, however, remains that we do not have decisive external evidence of a Hellenised school of thought in either one of these contexts that actually fits in the sense that members were educated in Greek culture as far as the external form is concerned but remained religiously conservative.

Recently, scholars have found a direct line from the Museum of Alexandria and ancient Hebrew Bible traditions. Gmerkin (2016) is of the opinion that these Alexandrian scholars from the Alexandrian museum were actually responsible for preserving and even creating the traditions of the Hebrew bible. This hypothesis, however, has not yet received universal consensus (see also Evangelia Dafni on Platonism and the Hebrew Tradition [Dafni 2006]).

There are thus no direct parallels, but the author is working on the basis of the hypothesis that, in the wake of the Antiochian crisis, resistance in Palestine against Hellenising influences was more severe and orchestrated than in Egypt. As demonstrated above, there is evidence that active Hellenising also took place in Palestine. The first book of Maccabees is an applicable example. There are also other parallels to such a historical situation.

The complicated biblical book of Esther seems to the author to underscore this inference. ${ }^{11}$ The research conducted by De Troyer is of special significance. She studied the end of the alpha text (AT) of Esther in comparison with the MT and the LXX. ${ }^{12}$ As a representative portion, she dealt with one chapter, chapter 8 , and its parallel in the AT. She works strictly with reference to context (De Troyer 2000:86) and, as far as the Greek translation is concerned, studies two issues: the translational and the 'narrative technique' of the translator (De Troyer 2000:85). She also analysed each of these texts individually before determining their mutual interdependence (De Troyer 2000:71).

De Troyer demonstrates that the translator translated the Semitic parent text less faithfully and in the process introduced new dimensions into the text and transformed it into a new narrative (De Troyer 2000:398). Hence, the adaptation of the narrative took place on various levels. Among other things, she finds it significant that the epithet 'the Agagite' is not rendered in the LXX.

She argues convincingly that the translator actually transforms the distant relationship between the king and Esther in MT

10.There is a shortage of Jewish literature written in Greek in Israel (Collins 2006b:45). 11.For an exhaustive interpretation, see Cook and Van der Kooij (2012:169-174). 12.See my review of this monograph in Hebrew Studies Journal (Cook 2005:433-437). 
into an I-you relationship in verses 3-8 (De Troyer 2000:274). The same applies also to her inference that he adapts the Hebrew narrative in order to clarify matters. This applies to verse (v.) 6, where Esther asks how she can be saved from the destruction of her fatherland ( $\pi \dot{\alpha} \tau \rho ı \varsigma)$. Also, as far as v. 13 goes, the emphasis is clearly placed on the Jews and what they are at liberty to do in order to fight against their enemies. The adaptations in the Greek version of verse 11, 'to act according to their laws in every city', act as a confirmation in this regard.

Other significant adaptations of the Hebrew appear in v. 9, where the date on which scribes are summoned together is changed. This date apparently agrees with a statement in 2 Maccabees that De Troyer utilises for dating purposes (De Troyer 2000:275). The translator also makes a distinction between those to whom the letters are written and those who are placed under the king's orders in verse 9.

De Troyer's interpretation of Haman as the main adversary, not only of the Jews but also of the king, is of critical importance for our understanding of LXX Proverbs. This applies to the depiction of Haman as the Macedonian. Haman is referred to as the son of Hammedatha, the Agagite, in MT 3:10; 8:3 and 8:5. In all these passages, the LXX translator mentions Haman without the additional designation; however, in chapter 9:24, Haman is depicted as the son of Hammedath the Macedonian. De Troyer (2000:194) argues that this is evidence that the translator indeed deliberately interprets the feud between the Jews and a foreign nation as one between the Jews and the Greeks. It must be remembered that this translator operated within a Hellenistic context, which is clear from his specifications of the Greek polis in verse 15 (De Troyer 2000:194).

De Troyer places LXX Esther historically for "The LXX translated and interpreted the Esther narrative in the light of the events of the year 164 BCE' (De Troyer 2000:398). This is the year that Antiochus IV Epiphanes died. She also found terminology and imagery that correspond with those in the decrees of Antiochus IV and V. In this regard, verse 15 in the Greek seems to correspond with the images of the high priests described in 1 Maccabees. Mordecai, for instance, is presented as a high-priestly figure and perceived as the friend of the king and receives a golden crown, as did Jonathan and Simon (De Troyer 2000:276).

De Troyer (2000:398) thus found evidence that the letters of Antiochus IV and V actually served as a major source of inspiration to this translator, which naturally has implications for the dating of the translation. In this regard, De Troyer agrees with Bickerman (1944:339-362; 1950:101-133), who studied the colophon of LXX Esther and concluded that its translation came into existence in Jerusalem ${ }^{13}$ during the time of Alexander Jannaeus and that

13. Boyd-Taylor (1997:88, 105) accepts a 2nd to 1st century BCE dating, but is uncertain about the Palestinian provenance of Greek Esther. Fox (1991:37) seems to be in agreement with Bickerman's position, even though he thinks seems to be in agreement with Bickerman's position, even though he thinks
a later terminus a quo is also possible. Clines (1984:169) refers to 'religious additions' in the LXX without dating them. it was subsequently brought to Alexandria. This was done in order to introduce the Purim feast to Jews in Alexandria. Jobes (1996:230) agrees with this view.

It should therefore be clear that, as far as the issue of the anti-Hellenistic inclination of LXX Proverbs is concerned, the book of Esther can be taken as an important source for comparison. ${ }^{14}$ This is true even though the colophon witnesses to a later date. After all, as argued by De Troyer, Esther was translated earlier. To quote one example again: Haman in the Septuagint is depicted as having some Greek characteristics; hence, he can be described as 'the Macedonian, the prototype of the threat from the west' (De Troyer 2000:276). This fits with my interpretation that LXX Proverbs has an apologetic intention ${ }^{15}$ and that the translator(s) of LXX Proverbs purposefully warned the readers against the dangers of the Hellenism of the day. ${ }^{16}$

Therefore, the author would suggest that the historical context for the Septuagint version of Proverbs could be deemed to be Jerusalem in the 2nd century BCE, sometimes after the Antiochian crisis. This context is characterised by the application of apocalyptic terminology.

At a conference held in Budapest ${ }^{17}$ in September 2017, the author demonstrated that LXX Proverbs was influenced indirectly by the reforms of Antiochus Epiphanes. In the final analysis, it is not possible to identify examples of direct influence of Antiochus Epiphanes in LXX Proverbs. There are no clear signs of Epiphanes' anti-Jewish activities or of his anti-monotheistic tendencies (Tcherikover 1985:175-179), nor of pagan monotheism (1959:182). The addition of the equivalent of the phrase in Proverbs 9:10(a) and 13:15 for to know the law is the sign of a sound mind could be the result of the persecutions. However, this need not be evidence of direct influence. The fact that LXX Proverbs is a translation of a biblical book problematises the issue. Another aspect addressed by this repeated phrase is that knowing the law of Moses is an intellectual feature and not barbaric superstition (Tcherikover 1985:198). The verb $\gamma v \tilde{\omega} v \alpha r$ and the adjective $\dot{\alpha} \gamma \alpha \theta \tilde{\eta} \varsigma$ are possible indications of intellectual activity, as is the statement in verse 7 - 'An intelligent son keeps the law'

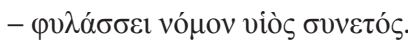

Having said that, there are many signs of indirect influence, of a community devastated by Hellenising activity, including going to the gymnasium naked and being taught anti-Jewish doctrines, and a focus on the individual rather than the communal (Goldstein 1976:200). Moreover, there seems to be

14.Feldman (2002:303) states that the additions to Esther, 'far from showing the influence of Hellenism, are more conservative than those found in the Hebrew version'.

15.This is characterised by the application of apocalyptic terminology, which the author described as a moralising tendency in the Festschrift of Siegfried Mittmann (Cook 2004). The author interpreted the moralising tendency in LXX Proverbs as an indication of apocalyptic thought (Cook 1999:251-261).

16.See the paper entitled 'The Septuagint of Proverbs in the light of Antiochus Epiphanes' devastating reforms' presented at the Károli Gáspár University, Budapest, Hungary, in September 2017.

17.The theme of the conference was Persecution, Passion and Epiphany in Early Jewish Literature. 
support for the argument of Bickerman (1979:83) 18 that it was, in fact, Jewish Hellenisers ${ }^{19}$ who were responsible for the Hellenising of Palestine and not Antiochus Epiphanes.

\section{Conclusion}

The examples discussed above clearly indicate that the person responsible for LXX Proverbs was deeply steeped in Jewish and Greek culture. Moreover, he was a capable, independent author who, according to my interpretation, resided in Palestine during or just after the Antiochian crisis. This historical context displays clear signs of apocalyptic terminology and thinking, like the abundant application of contrasts between good and evil (Cook 1999; 2017:18). This should come as no surprise as Gerhard von Rad (1972:314) connected Wisdom with Apocalypticism.

\section{Acknowledgements Competing interests}

The author declares that he has no financial or personal relationships which may have inappropriately influenced him in writing this article.

\section{References}

Aejmelaeus, A., 1993, On the trail of the septuagint translators. Collected essays, Kampen, Kok.

Ausloos, H. \& Lemmelijn, B., 2010. 'Content-related criteria in characterising LXX translation technique', in W. Kraus, M. Karrer \& M. Meiser (eds.), Die Septuaginta - Texte, Theologien, Einflüsse. 2. Internationale Fachtagung von Septuaginta Deutsch (LXX. D), Wuppertal 23.-27.7.2008, pp. 356-376, WUNT 252, Moh Siebeck, Tübingen

Ausloos, H., Lemmelijn, B. \& Kabergs, V., 2012, 'The study of aetiological wordplay as a content-related criterion in the characterisation of LXX translation technique', in S. Kreuzer, M. Meiser \& M. Sigismund (eds.), Die Septuaginta - Entstehung, Sprache, Geschichte, pp. 273-294, WUNT 286, Mohr Siebeck, Tübingen.

Bassnett, S. \& Trevedi, H., 1999, Post-colonial translation: Theory and practice, Routledge, London.

Bickerman, E.J., 1944, 'The Colophon of the Greek book of Esther', JBL 63, 339-362.

Bickerman, E.J., 1950, 'Notes on the Greek book of Esther', PAAJR 20, 101-133.

Bickerman, E.J., 1979, The God of the Maccabees. Studies on the meaning and origin of the Maccabean Revolt, Brill, Leiden.

Boyd-Taylor, T.C.R., 1997, 'Esther's great adventure: Reading the LXX version of the book of Esther in the light of its assimilation to the conventions of the Greek Romantic Novel', BIOSCS 30, 88-105.

Boyd-Taylor, T.C.R., 2005, 'Reading between the lines - Towards an assessment of the interlinear paradigm for septuagint studies', PhD thesis, University of Toronto.

Clines, D., 1984, The Esther scroll. The story of the story, JSOTSS 30, Sheffield University Press, Sheffield.

Collins, J.J., 2006a, 'Hellenistic Judaism in recent scholarship', in J.J. Collins (ed.) Jewish Cult and Hellenistic culture. Essays on the Jewish encounter with Hellenism and Roman rule, pp. 1-20, Brill, Leiden.

Collins, J.J., 2006b, Jewish Cult and Hellenistic culture: Essays on the Jewish encounter with Hellenism and Roman rule, Supplements to the Journal for the Study of Judaism 100, Brill, Leiden.

Cook, J., 1995, 'Were the persons responsible for the septuagint translators and/or scribes and/or editors?', JNSL 21(2), 1-12.

Cook, J., 1997, The septuagint of proverbs - Jewish and/or Hellenistic proverbs? concerning the Hellenistic colouring of LXX Proverbs, Vetus Testamentum Supplementum 69, Brill, Leiden.

Cook, J., 1999, 'Apocalyptic terminology in septuagint proverbs', JNSL 25(1), 251-261.

Cook, J., 2001, 'Ideology and translation technique - Two sides of the same cfoin?', in R. Sollamo \& S. Sipilä (eds.), Helsinki perspectives on the translation technique of the Septuagint, pp. 195-210, VandenHoeck \& Ruprecht, Göttingen.

18.See the discussion by Tcherikover (1985:183).

19.Bickerman (1997:84) interprets the cause of the lawless of I Maccabees 1:11 as the Hellenisers. See the discussion by Goldstein (1976:200).
Cook, J., 2002, 'The translator(s) of LXX proverbs', TC - A Journal of Biblical Textual Criticism 7, 1-50.

Cook, J., 2003, 'The Greek of proverbs - Evidence of a recensionally deviating Hebrew text?', in S.M. Paul, R. Kraft, L.H. Schiffman \& W.W. Fields (eds.), Emanuel: Studies in Hebrew Bible, Septuagint, and Dead Sea Scrolls in Honor of Emanuel Tov, pp. 605-618, Brill, Leiden.

Cook, J., 2004, 'Exegesis in the septuagint', Festschrift for Prof. Dr. Siegfried Mittmann, JNSL 30, 1-19.

Cook, J., 2005, 'Review of De Troyer, K., 2000, The End of the Alpha Text of Esther. Translation and Narrative Technique in MT 8:1-17, LXX 8:1-17, and AT 7:14-41, SCS 48, SBL, Atlanta GA', Hebrew Studies 46, 433-437. https://doi.org/10.1353/ hbr.2005.0020

Cook, J., 2006, 'The translation of a translation: Some methodological considerations on the translation of the Septuagint', in M.K.H. Peters (ed.), Congress volume of the IOSCS Leiden 2004, pp. 29-40, SBL, Leiden.

Cook, J., 2017, 'Interpreting the Septuagint', in C. Maier, L.C. Jonker \& G.R. Kotzé (eds.), Congress volume Stellenbosch 2016, VTS 176, pp. 1-22, Brill, Leiden.

Dafni, E., 2006, 'Platos Symposion und die Septuagintafassung Gen 2,23, Methodische Überlegungen zum Austausch von hebräischem und griechischem Sprach- und Gedankengut in der Klassik und im Hellenismus', OTE 19(3), 1139-1161.

De Troyer, K., 2000, The end of the alpha text of Esther. Translation and narrative technique in MT 8:1-17, LXX 8:1-17, and AT 7:14-41, SCS 48, SBL, Atlanta, GA.

D'Hamonville, D.M., 2000, Les proverbes, La Bible d'Alexandrie 17, Serf, Paris.

Evan-Zohar, I., 1990, 'Polysystem theory', Poetics Today 11(1), 9-26. https://doi. org/10.2307/1772666

Feldman, L.H., 2002, 'How much Hellenism in the land of Israel?', JSJ 32, 290-313.

Fox, M.V., 1991, The redaction of the book of Esther, SBLMS 40, SBL, Atlanta GA.

Fox, M.V., 2002, 'Translation and Mimesis', in F.W. Knobloch (ed.), Biblical translation in context, pp. 207-221, University Press of Maryland, Bethesda, MD.

Fox, M.V., 2015, Proverbs: An eclectic edition with introduction and textual commentary, The Hebrew Bible: A critical edition 1, SBL Press, Atlanta, GA.

Gerleman, G., 1950, 'The Septuagint proverbs as a Hellenistic document', OTS 8, 15-27.

Gmerkin, R., 2016, Plato and the creation of the Hebrew Bible, Copenhagen International Seminar, Routledge, Abingdon.

Goldstein, J.A., 1976, I Maccabees. A new translation with introduction and commentary, AB 41, Doubleday, New York.

Hengel, M., 1974, Judaism and Hellenism: Studies in their encounter in Palestine during the early Hellenistic period, SMC Press, London.

Jobes, K.H., 1996, The alpha-text of Esther. Its character and relationship to the Massoretic text, SBLDS 153, SBL, Atlanta, GA.

Lemmelijn, B., 2007, 'Free and yet faithful: On the translation technique of LXX Exod 7:14-11:10', JNSL 33(1), 1-32.

Lemmelijn, B., 2009, A plague of texts? A text-critical study of the so-called 'Plagues Narrative' in Exodus 7:14-11:10, OTS 56, Brill, Leiden.

Naudé, J.A., 2009, 'The book of aristeas and modern translations of the Septuagint', Acta Patristica et Byzantina 20, 259-274. https://doi.org/10.1080/10226486.200 9.11879109

Pietersma, A., 2002, 'A new paradigm for addressing old questions: The relevance of the interlinear model for the study of the Septuagint', in J. Cook (ed.), Computer and Bible: The Stellenbosch AIBI-6 Conference. Proceedings of the Association Internationale Bible et Informatique 'From Alpha to Byte', University of Stellenbosch, 17-21 July, 2000, Brill, Leiden, pp. 337-364.

Rösel, M., 2008, 'Schreiber, Übersetzer, Theologen. Die Septuaginta als Dokument der Schrift-, Lese-, und Übersetzungskulturen des Judentums', in M. Karrer, W. Kraus \& M. Meiser (eds.), Die Septuaginta - Texte, Kontexte, Lebenswelten, Internationale Fachtagung veranstaltet von Septuaginta Deutsch (LXX. D), Wuppertal 20. -23 . Juli 2006, pp. 83-102, WUNT 219, Mohr Siebeck, Tübingen.

Tcherikover, V., 1985, Hellenistic civilization and the Jews, transl. S. Applebaum, Atheneaum, London.

Toury, G., 1995, Descriptive translation studies and beyond, John Benjamins, Amsterdam.

Tov, E., 2010, 'Reflections on the Septuagint with special attention paid to the post-pentateuchal translations', in W. Kraus, M. Karrer \& M. Meiser (eds.), Die Septuaginta - Texte, Theologien, Einflüsse. 2. Internationale Fachtagung von Septuaginta Deutsch (LXX. D), Wuppertal 23. -27.7.2008, WUNT 252, Mohr Siebeck, Tübingen, pp. 3-22.

Tov, E. \& Wright, B.G., III, 1985, 'Computer-assisted study of the criteria for assessing the literalness of translation units in the LXX', Textus 12, 149-187.

Van der Louw, T.A.W., 2007, Transformations in the Septuagint. Towards an interaction of Septuagint studies and translation studies, CBET 47, Peeters, Leuven.

Von Rad, G., 1972, Wisdom in Israel, SCM Press, London.

Wacholder, B.Z., 1974, Eupolemus. A study of Judeao-Greek literature, Hebrew Union College, Cincinnati, $\mathrm{OH}$.

Wevers, J.W., 1985, 'An Apologia for Septuagint studies', BIOSCS 18, 16-38. 